\title{
Mestring før kreftoperasjon
}

\begin{abstract}
Det er viktig at kvinner med brystkreft som venter på operasjon får gradvis tilpasset informasjon og lever et så normalt liv som mulig.
\end{abstract}

H ensikten med denne artikkelen er å belyse hvordan kvinner med nylig diagnostisert brystkreft som venter på operasjon, mestrer sin situasjon. Artikkelen er basert på funn fra mitt doktorgradsprosjekt hvor 21 kvinner med nylig diagnostisert brystkreft ble individuelt intervjuet dagen før operasjon $(1,8)$ :

«Det er lettere for meg hvis jeg tar det steg for steg. Det gjør meg roligere. Jeg prøver å skyve vekk de verste muligheter». «Når jeg har fått den beskjeden, så må jeg fordøye den og så får jeg neste beskjed og så må jeg fordøye den». «I begynnelsen, brukte jeg mye tid på internett, men jeg bestemte meg for å stoppe. Det var lite å finne som er positivt. Jeg liker å ha kontroll, og plutselig fant jeg ut at alt er utenfor min kontroll».

Sitatene ovenfor illustrerer noen av kvinnenes mestringsforsøk i den vonde ventetiden mellom diagnose og operasjon. Mestring kan defineres på ulike måter. Lasarus (9) definerer mestring som «kontinuerlige skiftende kognitive og atferdsmessige anstrengelser for å takle spesifikke ytre eller indre krav som oppleves som belastende, eller som overskrider ens ressurser».

\section{Hovedbudskap}

Beskrivelser av mestringsopplevelser hos kvinner med nylig diagnostisert brystkreft før operasjon. Det er viktig å være oppmerksom på likheter og variasjoner i kvinnenes mestringsstrategier for å styrke deres integritet og mestringsopplevelse i denne vanskelige ventetiden.

\section{Nøkkelord}

Les mer og finn litteraturhenvisninger på våre nettsider. \Kreft \Mestring \Kirurgi \Kvinne \Intervju

\section{Bakgrunn}

Å bli diagnostisert med brystkreft er for mange kvinner en traumatisk opplevelse som innebærer kaos, usikkerhet, angst og håpløshet og utfordrer mestringsevnen $(1,2)$. Hvert år får hver tiende kvinne i Norge brystkreft og det rammer først og fremst kvinner over 50 år. Cirka 88 prosent av dem som får brystkreft overlever etter fem år. Imidlertid har man også sett at det kan komme tilbakefall etter så lang tid som 20 år (3). Det innebærer at brystkreft er en lite forutsigbar sykdom, og mange pasienter lever i konstant usikkerhet. Hvordan kvinner reagerer og mestrer den usikre ventetiden før operasjonen spiller en vesentlig rolle for hvordan de mestrer sin situasjon senere, og kan også være avgjørende for hvordan de klarer seg gjennom behandlingen (4). Å akseptere at man har fătt en brystkreftdiagnose, uten at man tenker på den hele tiden, er viktig for å takle sykdommen best mulig (5). Det viser seg at de kvinnene som mestrer sykdomsperioden dårlig også sliter psykisk flere år senere. Slik manglende mestring har også vist sammenheng med tidlig død og kreft-tilbakefall $(6,7)$.

I møte med et helsevesen preget av effektivisering og markedsøkonomisk tenkning kan pasienten lett bli behandlet som et medisinsk objekt ved at helsepersonell ikke har tid til pasientens personlige bekymringer. Økt poliklinisk behandling og redusert liggetid i sykehus vil også gi helsepersonell mindre tid i møte med pasienten og mindre mulighet til å gi omsorg. Dette gjør det enda viktigere å være til stede i det enkelte møtet og være oppmerksom på pasientens reaksjoner og mestringsopplevelse. Det er viktig å gi individualisert omsorg i behandling og oppfølging slik at pasientens mestringsressurser kan styrkes på en god måte.

\section{Forsvarsmekanismer}

Funnene viste at «steg for steg» var den mest hensiktsmessige mestringsstrategien for å unngå å bli overveldet av truende tanker og følelser. For mye informasjon om gangen, enten fra sykehuset eller internett, var skremmende. Noen følte de mistet kontrollen fordi informasjonen var så overveldende. Ved å ta det inn over seg litt etter litt kunne de gradvis forholde seg til en endret situasjon, og prosessen med å akseptere hva som ville komme ble lettere. Det ga også en følelse av kontroll over en situasjon de primært oppfattet som utenfor deres kontroll. Ifølge Lazarus (9) innebærer «stegfor-steg» som mestringsstrategi en blanding av følelsesfokusert mestring og unngåelsesfokusert mestring som fungerer samtidig og som utfyller hverandre i forsøket på å få kontroll over følelsene og en utfordrende situasjon.

Forsvarsmekanismene må vurderes ut fra hvilke funksjon de har i den aktuelle situasjonen. De kan virke beskyttende i en vanskelig situasjon ved å redusere indre spenninger og bidra til å opprettholde stabilitet i følelseslivet slik at optimisme opprettholdes (10). Forsvarsmekanismer kan være bra i en kort periode når man blir stilt overfor plutselige påkjenninger og livstruende sykdom, men over lengre tid kan det gi mer angst og problemer $(11,12)$. Funnene viste at noen av kvinnene distanserte seg følelsesmessig fra sin sykdom og forsøkte, med varierende resultater, å skyve vekk vanskelige, kaotiske tanker og følelser. De visste de hadde kreft, men ingen kjente til hvor alvorlig det kunne være. Mange hadde vansker med å akseptere diagnosen samtidig som de følte seg friske. Skremmende utsikter kunne dominere tankene og følelsene deres. Noen jobbet hardt for å skyve vekk de smertefulle tankene, men uansett hvor hardt de prøvde kom tankene tilbake: «Jeg prøver 


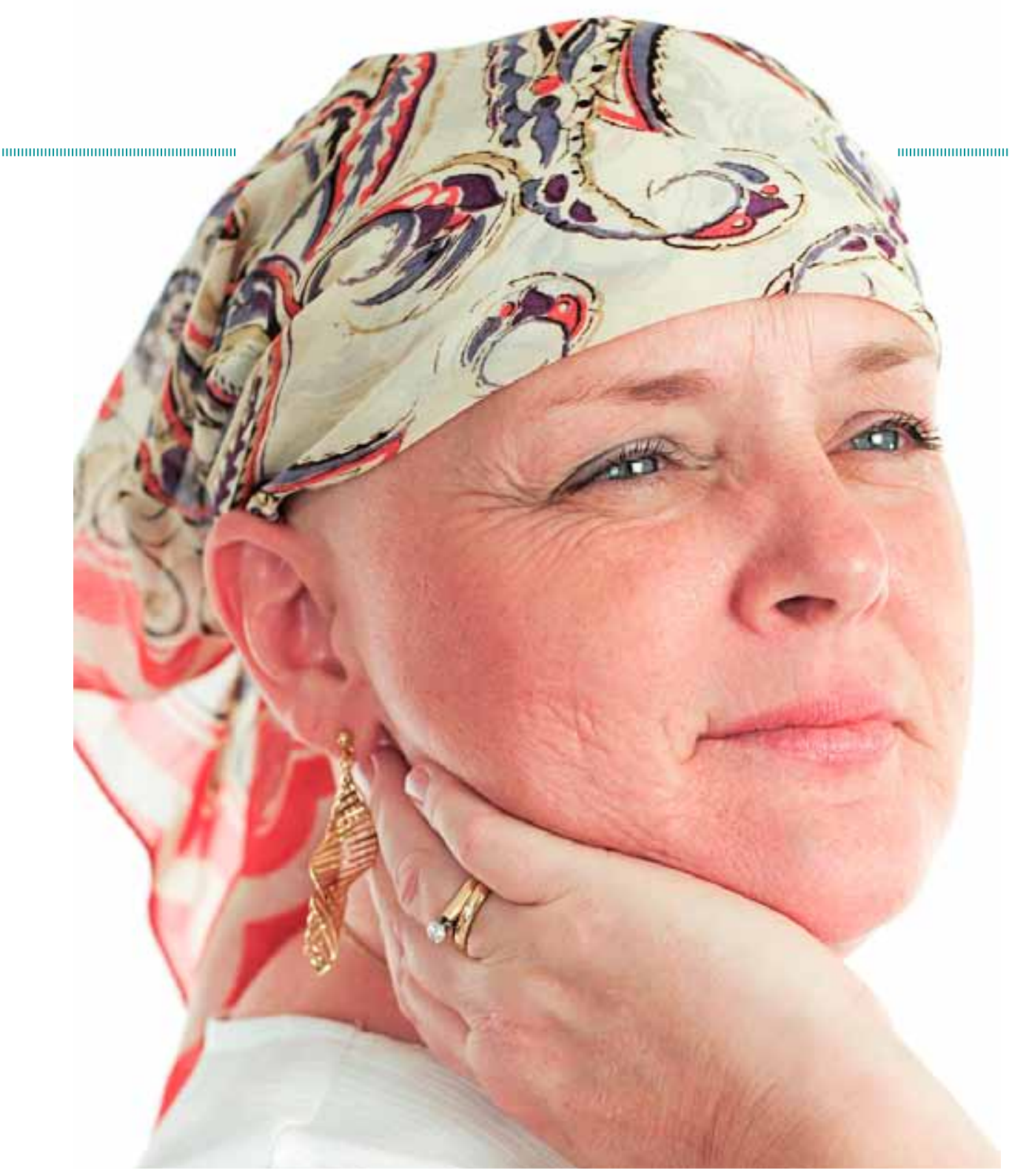

TøFF TID: Hvordan kvinner som venter på brystkreftoperasjon mestrer ventetiden kan være avgjørende for hvordan de klarer seg gjennom behandlingen og i ettertid. Illustrasjonsfoto: (C) Lisa F. Young.

å skyve tankene vekk. Uansett hva jeg gjør, kommer disse tankene tilbake». Å holde distanse ved å engasjere seg og være opptatt med andre ting, som hobbyer eller arbeid, var den mest hensiktsmessige mestringsstrategien. Fysisk trening ble opplevd som spesielt nyttig. Det ga dem positive tanker og følelser, men også fysisk og mental styrke. Andre studier har også vist god effekt av fysisk trening hos kvinner med brystkreft (13). Å være sammen med andre var også nyttig - ikke bare som følelsesmessig støtte, men også som en måte å holde truende tanker og følelser vekk på gjennom å engasjere seg i kjekke aktiviteter: «Mine venner hjelper meg til å tenke på andre ting, slik at ventetiden går fortere».

\section{Tap av kontroll}

I denne situasjonen handlet mye av usikkerheten om tap av kontroll. Mestring er forbundet med opplevelse av kontroll. Personer som opplever tap av kontroll over sin egen situasjon synes å ha mer stressrelaterte problemer enn de som tror de kan påvirke sin situasjon (9). Mange pasienter med brystkreft nevner tap av kontroll, noe som har vist seg å skape hjelpeløshet og depresjon. Det å få vite datoen for operasjon så fort som mulig var derfor viktig. Det ga dem en følelse av kontroll og av å tilhøre et pålitelig helsevesen, og lindret angst, usikkerhet og den uutholdelige ventetiden. Alle kvinnene var blitt fortalt at de kunne ringe sykepleier for rådgivning, når som helst. Hjelp og støtte fra helsepersonell er uvurderlig, og de kan lette pasientenes usikkerhet ved å gi dem tilpasset medisinsk informasjon og hjelpe dem til å sortere og korrigere den kunnskapen de måtte ha om diagnosen. Dette kan bidra til $ø \mathrm{kt}$ forståelse av situasjonen og gi en opplevelse av å mestre (8). Stress og angst kan midlertidig redusere pasientens evne til kognitiv informasjonsbearbeiding, særlig i krisens akutte fase (14). Funnene viste at informasjonen de hadde fătt av legen var vanskelig å huske. Til tross for at mange hadde behov for profesjonell rådgivning og å ha en trygg og tillitsfull dialog for å komme ut av skremmende grublerier, var mange redde for å forstyrre og usikre på sin rolle som pasient, som sitatene illustrer: «Jeg vil ikke forstyrre. Leger og sykepleiere har det travelt. Det er ikke bare meg.» «Jeg føler det er veldig vanskelig å snakke med noen som jeg aldri har møtt.» «Det ville være mye lettere for meg hvis initiativet hadde kommet fra sykehuset.»

\section{Leve som normalt}

At livet fortsatte så normalt som mulig i venteperioden, ga kvinnene en følelse av kontroll. Arbeid ga pusterom og muligheten til å fokusere på andre ting, i tillegg var det å være inkludert i det sosiale fellesskapet på en arbeidsplass også av stor verdi: «Jeg er redd og nervøs for det som skal skje. Men samtidig så holder jeg fast på de tingene jeg vanligvis gjør; går på jobb og synger i kor.» «Det viktig for meg å være i arbeid og ikke å kjenne på redsel. Det gir meg en følelse av å ha kontroll over noe i livet mitt.» De fleste ønsket å bli behandlet som vanlig. Noen kunne bli sårbare og redde av for mye trøst og medfølelse fra bekymrete og sjokkerte familiemedlemmer, kollegaer og venner: «Hvis noen synes synd på meg, begynner jeg å synes synd på meg selv.» Noen valgte derfor å forholde seg hovedsakelig til personer som behandlet dem som vanlig og som ikke dramatiserte situasjonen.

\section{Finne mening}

Kvinnenes eksistens, verdier og grunnleggende behov for mening og forutsigbarhet ble truet, og mange slet med å finne mening i den usikre situasjonen. Noen bearbeidet usikkerheten ved å stille seg spørsmål om meningen med livet, hva som betydde mest og ga dem glede, og positive følelser. Kreftdiagnosen ble en påminnelse om å

\section{«Mine venner hjelper meg til à tenke på andre ting, slik at ventetiden går fortere».}

leve i øyeblikket og å sette mer pris på livet. De opplevde hver dag som viktig: «Siden jeg fikk denne meldingen, tror jeg det er en mening. Kanskje jeg skal lære å sette pris på andre ting.» «Jeg kommer til å sette mer pris på de gode dagene.» De som fant mening $\mathrm{i}$ å prioritere det som betydde mest for dem oppdaget at dette hjalp dem til å takle usikkerhet og dødsangst. Forskning viser at en slik strategi er hensiktsmessig for å kunne takle traumatiske opplevelser og reaksjoner (15). Noen av kvinnene 
klarte å se de positive sidene ved det å ha fătt brystkreft og ble overbevist om at de på sikt ville komme styrket ut av det.

\section{Åpenhet \\ Å holde følelsene på avstand var viktig for noen, mens andre følte det både som en lettelse og som terapi når de fikk snakke om diagnosen og vise følelser: «Jeg var ikke en del av det før jeg klarte å snakke gjennom noen av følelsene og gråte litt.» «Jeg føler jeg har snakket mye, både hjemme og med andre som er nær meg. For meg har det vært en terapi.» Noen følte også det var godt å gråte og «slippe masken» når de var sammen med noen som de oppfattet som støttende og som virkelig \\ «Jeg vil ikke forstyrre. Leger og sykepleiere har det travelt.»}

lyttet. Forskning viser at å uttrykke følelser og sette ord på opplevelser og erfaringer er en god mestringsstrategi for å redusere usikkerhet og angst, spesielt når man kan betro seg til noen man har tillit til (16). Andre skrev dagbok for å rydde opp i kaotiske tanker og følelser: «Jeg kan skrive både om glede og fortvilelse. Ingen kan kommentere det.» Å skrive om traumatiske og stressende hendelser har vist seg å være et godt utgangspunkt for å jobbe med egne tankemønstre og reaksjoner og det bedrer både fysisk og psykisk helse (17).

Imidlertid var åpenhet og følelsesutbrudd et tveegget sverd i denne situasjonen. Det framkalte følelser av svakhet og selvmedlidenhet og reduserte følelsen av mestring: «Det hjelper ikke å gråte, da føler jeg bare selvmedlidenhet.» Teorier om sorg og krise har vist at det er mulig å komme gjennom traumatiske situasjoner uten å gråte (18). Mange undertrykte følelsene sine for å kunne leve så normalt som mulig, men også for å unngå ubehagelige, energitappende spørsmål og reaksjoner fra andre.

\section{Håp}

Kvinnene var klar over at de kunne dø, men samtidig håpefulle og optimistiske, et dobbelt fokus som har også er blitt rapportert i lignende undersøkelser (19). Kvinnenes håp og optimisme var knyttet til en positiv innstilling og tro på egne ressurser og tidligere positive mestringserfaringer: «Jeg har alltid vært en optimist og har trodd at de fleste ting går bra.» «Jeg har vært gjennom tøffe tider før, men jeg har aldri gitt opp.» Tidlig påvisning av kreft, tillit til sykepleiere og leger, men også det å vite at brystkreft har en god prognose styrket deres mestringsopplevelse og ga dem håp. Håp er nært knyttet til mestring og defineres som den fundamentale kunnskapen om at det er en vei ut av vanskelighetene. Håp kan sees på som motsatsen til håpløshet og hjelpeløshet, og håp hjelper mennesker til å tåle lidelse og usikkerhet. Håp og frykt er både sammenvevde og framtidsrettete følelser (15). I denne situasjonen var frykten for spredning og død skremmende muligheter, kvinnene var klar over at mestring ville være vanskelig og ta tid, men de fleste av dem hadde en sterk tro på fremtiden og positive forventninger til at de på sikt ville bli friske. De fleste var sikre på at de hadde ressurser i seg selv til å møte utfordringen som de sto overfor. Noen hadde i tidligere vanskelige livssituasjoner også opplevd å ha uventet styrke som ga dem forventninger om at de ville klare problemene også denne gangen. Å ha gode venner og være i god fysisk form bidro også til positiv tenkning og mestringsopplevelse.

\section{Tvil}

Uansett hvor hardt de prøvde å tenke optimistisk var pessimisme, negativ tenkning og tvil likevel alltid til stede. Noen hadde en generelt pessimistisk holdning til livet, holdninger som også er rapportert blant pasienter med brystkreft (6). Noen forberedte seg mentalt på «det store smellet». Dette kan være en framtidsrettet mestringsstrategi som innebærer å spare krefter til å kunne takle fremtidige vanskelige situasjoner (15). Andre fors $ø$ kte å håndtere pessimisme og negativ tenkning ved ikke å tenke så mye på muligheten for spredning og død, og på denne måten unngå uheldige grublerier og selvmedlidenhet. Grublerier og selvmedlidenhet førte til katastrofetanker som truet deres integritet og mestringsfølelse.

\section{Konklusjon}

Fra et klinisk sykepleieperspektiv er det viktig å være oppmerksom på både likheter og variasjoner i kvinnenes mestringsstrategier. Kvinnenes mestringsstrategier viste generelle mønstre slik som: Ta en ting av gangen, leve som før og bli behandlet av andre som vanlig. Behovet for å holde diagnosen på litt avstand var viktig for å unngå å bli overveldet av følelsesmessige reaksjoner. Det er viktig at helsepersonell gir gradvis tilpasset informasjon og anbefaler kvinnene å leve et så normalt liv som mulig. Verdien av å opprettholde et positivt fokus gjennom kjekke aktiviteter for unngå skadelig grubling, er også viktig i denne sammenhengen. Samtidig må helsepersonell også hjelpe kvinnene til å akseptere sin fortvilelse og depressive reaksjo- ner når, og om, de måtte komme. Man kan mestre situasjonen med en kreftsykdom både ved å involvere seg og engasjere seg, og ved å prøve å holde distanse og kontroll. Men mestringsmulighetene til den enkelte er likevel begrenset og påvirket av samspillet med familie, venner og kollegaer som også skal mestre situasjonen. Dessuten vil den enkeltes mestringsmuligheter alltid være påvirket av den enkeltes livshistorie, erfaringer, kunnskaper og alder. Funnene i mine undersøkelser gir kunnskap om kvinners mestringsopplevelser i en vond og vanskelig ventetid, og kan gi helsepersonell innsikt som kan brukes til å utvikle tiltak for å lette deres situasjon. Det er viktig med bevissthet om kvinnenes individuelle behov i denne vanskelige ventetiden for å styrke deres integritet og mestringsopplevelse. IIII

Jeg takker alle pasientene som deltok i studien og Avdeling for bryst- og endokrinkirurgi, Kirurgisk klinikk, Haukeland universitetssykehus. Og takk til professor Torill Christine Lindstrøm, UiB for faglig samarbeid og gjennomlesning av artikkelen.

\section{REFERANSER}

Drageset S, Lindstrøm TC, Underlid K. Coping with breast cancer: between diagnosis and surgery. J Adv Nurs. 2010 Jan; 66:149-58.

2. Drageset S. Vond ventetid. Sykepleien 2011:99:52-4.

3. Norwegian Breast Cancer Group. Brystkreft. Diagnostikk og behandling. En Veiledning. Oslo. 2011 (hentet 2013-21-01) Tilgjengelig fra: http://www. nbcg.no/nbcg.blaaboka.htm

4. Schou I, Ekeberg O, Ruland CM. The mediating role of appraisal and coping in the relationship between optimism-pessimism and quality of life. Psychooncology. 2005 Sep; 14:718-27.

5. Roussi PAE, Vagia, K. AE. Hatzidimitriou, C., Koutri, EE. Patterns of Coping, Flexibility in Coping and Psychological Distress in Women Diagnosed with Breast Cancer. Cogn Ther Res. 2007; 31:97-109.

6. Schou I, Ekeberg O, Ruland CM, Sandvik L, Karesen R. Pessimism as a predictor of emotional morbidity one year following breast cancer surgery. Psychooncology. 2004 May; 13:309-20.

Watson M, Homewood J, Haviland J. Coping response and survival in breast cancer patients: a new analysis. Stress and health. 2012 Dec: $28 \cdot 376-80$.

8. Draeset S. LindstramTC, Giske T. Underlid K Being in suspense:woments Drageset S, Lindstrøm TC, Giske T, Underlid K. Being in suspense: women experiences awaiting breast cancer surgery. JAdv Nurs 2011. 67:1941-51.

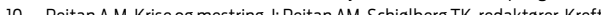
sykepleie pasient-utfordring-handling Oslo: Akribe AS, 2010:72-102.

sykepleie pasient-utfordring-handling Oslo.Aknbe AS, 2010.72-102. Drageset S, Lindstrom TC. Copingwith a possible areast cancer dlagnosis: demographic factors and social support. J Adv Nurs. 2005 Aug; 51: 217-26.

12. Jadoulle V, Rokbani L, Ogez D, Maccioni J, Lories G, Bruchon-Schweitzer M, \& Constant A. Coping and adapting to breast cancer: a six-month prospective study. Bull Cancer. 2006 Jul 1;93(7): E67-72.

3. Duijts SF, Faber MM, Oldenburg HS, van Beurden M, Aaronson NK. Effectiveness of behavioral techniques and physical exercise on psychosocial functioning and health-related quality of life in breast cancer patients and survivors - a meta-analysis. Psychooncology. 2011 Feb; 20:115-26.

14. Roy. The Roy adaptation model. London Upper Saddle River, NJ: Pearson. 2009.

5olkman S, Moskowitz JT. Coping: pitfalls and promise. Annu Rev Psychol. 2004:55:745-74.

16. Iwamitsu Y, Buck R. Emotional Distress in Breast Cancer Patients. Suppression of Negative Emotion Social Support. Clark, Anita V (Ed). 2005; Mood state and health. (pp. 87-119). viii: NY, US: Nova Biomedical Books.

17. Baikie AK, Wilhelm K. Emotional and physical health benefits of expressive writing. Advances in Psychiatric Treatment. 2005;11:338-46.

18. Stroebe MS, Folkman S, Hansson RO, Schut H. The prediction of bereavement outcome: development of an integrative risk factor framework. Soc Sci Med. outcome: development of

9. Rustoen T, Wiklund I. Hope in newly diagnosed patients with cancer. Cancer Nurs. 2000 Jun; 23: 214-9.

Fagartikler kan sendes til torhild.apall@sykepleien.no 